\title{
Spatial pattern analysis and demography of two tropical trees in the Brazilian Caatinga
}

\author{
Cristiane Gouvêa Fajardo¹, Maira Fontes Manzan¹, Fábio de Almeida Vieira \\ ${ }^{1}$ Universidade Federal do Rio Grande do Norte, Escola Agrícola de Jundiaí, RN 160 - KM 03 , Distrito de Jundiaí, CEP 59.280-000, Macaíba, RN, Brasil
}

"Autor correspondente:

vieirafa@yahoo.com.br

\section{Index terms:}

Aspidosperma pyrifolium

Caesalpinia pyramidalis

Cohorts

Plant coexistence

Spatial patterning

Termos para indexação:

Aspidosperma pyrifolium

Caesalpinia pyramidalis

Coortes

Coexistência de plantas

Padrão espacial

Histórico do artigo:

Recebido em 08/12/2013

Aprovado em 11/12/2014

Publicado em 31/12/2014

doi: 10.4336/2014.pfb.34.80.634
Abstract - Aspidosperma pyrifolium (Apocynaceae) and Caesalpinia pyramidalis (Fabaceae) share the same habitat in the Brazilian Caatinga domain. In this paper, we investigate the intra and inter-species interactions between these two plants using spatial pattern analysis among cohorts. The results showed that the adult trees of each species present higher densities at distances shorter than $9 \mathrm{~m}$ to $12 \mathrm{~m}$. However, due to seed dispersal via autochory, we expected a more aggregate density for $C$. pyramidalis than A. pyrifolium as the later disperses seeds through anemochory. Difference in spatial aggregation among cohorts was not observed and therefore the results contradict the expectations of the Janzen-Connell hypothesis. It is likely that this is associated with anthropogenic factors in the past such as fire, animal husbandry and logging. Using a bivariate analysis of the neighborhood density, we also confirmed the significant coexistence between the two species. This coexistence could be explained by the process of positive interspecific interactions, such as facilitation, which is common in semi-arid regions under stressful conditions.

\section{Padrão espacial e demografia de duas espécies arbóreas tropicais do bioma Caatinga}

Resumo - Aspidosperma pyrifolium (Apocynaceae) e Caesalpinia pyramidalis (Fabaceae) compartilham o mesmo habitat no bioma Caatinga. Neste trabalho, investigamos as interações intra e interespecíficas por meio do padrão espacial entre coortes. Os resultados mostraram que as plantas adultas de cada espécie apresentam elevados níveis de densidade em curtas distâncias ( 9 m e 12 m). No entanto, devido à dispersão de sementes via autocoria, esperávamos uma densidade mais agregada para C. pyramidalis do que em A. pyrifolium, que tem dispersão anemocórica. Não foi observada diferença de agregação espacial entre coortes e, portanto, os resultados contradizem as expectativas da hipótese de Janzen-Connell. É provável que isto esteja associado a fatores antrópicos no passado, tais como incêndio, pecuária e exploração madeireira. Por meio da análise bivariada da densidade de vizinhos, foi confirmada a coexistência significativa das duas espécies. Isto pode ser explicado pelo processo de interações interespecíficas positivas, tais como a facilitação, que é comum em regiões semiáridas, sob condições estressantes. 


\section{Introduction}

The Caatinga domain occupies $11 \%$ of the Brazilian territory with an area of approximately $800,000 \mathrm{~km}^{2}$. It occurs across the states of Piauí, Ceará, Rio Grande do Norte, Paraíba, Pernambuco, Alagoas, Sergipe, Bahia and in the north of Minas Gerais, covering $70 \%$ of Northeast region (Santos et al., 2011b). This domain occurs in areas with marked seasonality and low precipitation. It is an exclusive Brazilian domain and has shrub-tree vegetation composed mainly of xerophytic species (Costa et al., 2007). Recently, the flora of the Caatinga has received more detailed attention (Leal et al., 2005), but ecological studies are still in their early stages (Santos et al., 2011a). In relation to flora, for example, there are 932 recorded plants of which 380 are endemic species (Giulietti et al., 2004). Furthermore, eight floristic units were identified in the flora of the Caatinga, including the Arboreal Caatinga (Santos et al., 2012).

Aspidosperma pyrifolium Mart. (Apocynaceae) occurs in the Caatinga and is known as "pereiro", "pau-decoaru" and "pequiá-da-mata". It has winged seeds that are anemochorous. The tree grows up to $8 \mathrm{~m}$ in height. It is a heliophyte that occurs during secondary succession stages (Andrade et al., 2005). Caesalpinia pyramidalis Tul. (Fabaceae), known as "catingueira", is an endemic tree species that is characteristic of the Caatinga domain (Leite et al., 2009). It is a pioneer and autochorous species (Santana \& Souto, 2006).

A. pyrifolium and C. pyramidalis coexist in the same habitat in these dry forests. Thus, we investigated the intra and interspecific interactions between plants of these two species through an analysis of spatial pattern in order to evaluate the ecological traits and the processes shaping the distribution of plants (Vieira et al., 2010). The expectation is that the spatial distribution of the autochorous species is more aggregated than the anemochorous one (Vekemans \& Hardy, 2004). Furthermore, smaller trees (younger tree cohorts) must show a more aggregated spatial pattern than larger trees (adult tree cohorts) as mortality is a density-dependent (Vieira et al., 2012). Such a dependence is expected based on the so-called Janzen (1970) and Connell (1971) effect.

Generally, spatial patterning analyses have shown that the majority of tropical tree species exhibit a decrease in aggregation with an increase in age (Epperson \&
Alvarez-Buylla, 1997, Ng et al., 2004, Vieira et al., 2012), determined primarily by the intra and interspecific competition (Condit et al., 2000). However, low densities of reproductive adults and anthropogenic factors (e.g. grazing by domesticated animals) can limit recruitment and the species capacity for regeneration (Perevolotsky \& Haimov, 1992; Oba, 1998). Thus, we evaluated the spatial distribution and demography of $A$. pyrifolium and C. pyramidalis and used the spatial analysis to assess the existence of interspecific spatial interaction.

\section{Material and methods}

\section{Study site and sampling}

The study site is an 0.25 ha area in the Estação Ecológica do Seridó (ESEC), an area of the Caatinga domain in the municipality of Serra Negra do Norte, Rio Grande do Norte State, Brazil. The local flora is characterized by small trees, often with less than $7 \mathrm{~m}$ in height, with sparse distribution and fewer species than other types of caatinga (Santana \& Souto, 2006). However, the open characteristic does not match the original condition of vegetation, as a result from environmental degradation caused by human action, possibly through the successive burning carried out since the human colonization for the formation of pastures. The ESEC has a total area of 1,166 ha, altitude of 249 $\mathrm{m}$ and it is located between the geographic coordinates $06^{\circ} 36^{\prime} 40^{\prime \prime} \mathrm{S}$ and $06^{\circ} 33^{\prime} 50^{\prime \prime} \mathrm{S}$ and $37^{\circ} 17^{\prime} 10^{\prime \prime} \mathrm{W}$ and $37^{\circ} 14^{\prime} 20^{\prime \prime} \mathrm{W}$. The semiarid local climate, according to the Thornthwaite \& Mather (1955) classification, is a dry DdA'a' with an average annual precipitation of $733.7 \mathrm{~mm}$ and average annual temperature of $27.5^{\circ} \mathrm{C}$ (Santana et al., 2006).

Within the studying plot, individuals of $A$. pyrifolium and $C$. pyramidalis were recorded and their positions mapped ( $x$ and $y$ ). The plot included 285 individuals which were divided into three classes (cohorts) according to circumference at soil height (csh). For $A$. pyrifolium, the size classes of the cohorts (csh) were adults $(26 \mathrm{~cm}$ to $79 \mathrm{~cm})$ and juveniles $(5 \mathrm{~cm}$ to $25 \mathrm{~cm})$. For $C$. pyramidalis, the cohorts were adults $(27 \mathrm{~cm}$ to $83 \mathrm{~cm}$ ), juveniles $(7 \mathrm{~cm}$ to $26 \mathrm{~cm})$ and seedlings $(1 \mathrm{~cm}$ to $6 \mathrm{~cm}$ ).

\section{Spatial pattern analysis}

To determine if the spatial pattern for a single species is aggregated (univariate analysis) and if there is a spatial 
association between both species (bivariate analysis), we used a second order neighborhood density function (NDF; Condit et al., 2000). The NDF is statistically similar to Ripley's K function; however, it is not cumulative (Perry et al., 2006). Distance classes ( $t$ ) between $2 \mathrm{~m}$ and $24 \mathrm{~m}$ were used based on Haase (1995) suggestion that they do not exceed approximately $1 / 2$ the length of the smallest plot dimension. Additionally, we corrected the edge effect based on Goreaud \& Pelissier (1999). The NDF values were plotted in correlograms based on the distance $(t)$. The $99 \%$ confidence interval (CI) was estimated using a Monte Carlo method with 499 replicates for a $\alpha=0.01$. We used a Cramer-von Mises $(C v M)$, which is the sum of the squared difference between the observed and expected values under the null hypothesis, across all distance classes $(0-24 \mathrm{~m})$. These calculations were analyzed with SpPack 1.38 (Perry, 2004).

In order to examine if the spatial pattern of the two species are correlated, the sampled area was subdivided into 100 plots of $5 \mathrm{~m} \times 5 \mathrm{~m}$ and we calculated the number of individuals of each species within each sub-plot. A non-parametric correlation test was performed using Spearman correlation coefficient $\left(r_{s}\right)$ in the Statistica software (StatSoft, 2004).

\section{Results}

\section{Demography}

We sampled a total of 89 individuals of $A$. pyrifolium; of these 72 were adults (BIG), 16 juveniles (MED), and no seedlings (SMA) were recorded (Figure 1A). For $C$. pyramidalis we found 196 individuals: 126 adults, 61 juveniles and nine seedlings (Figure 1B). The densities within the 0.25 ha plot were 504 trees ha-1 $(\mathrm{BIG})$, 244 trees ha-1 (MED) and 36 trees ha ${ }^{-1}$ (SMA) for $C$. pyramidalis, and 288 trees ha ${ }^{-1}(\mathrm{BIG})$ and 64 tree ha $^{-1}$ (MED) for A. pyrifolium.

\section{Spatial Pattern}

The analysis of the spatial pattern of all $A$. pyrifolium $(N=89)$ individuals showed the density within a radius of $12 \mathrm{~m}$ was higher than expected for a hypothesis of complete randomness $(C v M=15.39, P=0.002)$ and a random spatial pattern was observed for all other distance classes (Figure 2A). For C. pyramidalis $(N=$ 196), our results showed significant levels of aggregation below the radius of $9 \mathrm{~m}$ from the focal individual $(\mathrm{CvM}$ $=1.57, P=0.002$ ) and random spatial pattern in the subsequent distance classes (Figure 2B).

The spatial distribution of seedling (SMA) and juvenile (MED) individuals $(N=70)$ of $C$. pyramidalis was significantly different from that expected for a random distribution $(C v M=5.49, P=0.002)$ (Figure 3A). For this analysis we combined the SMA and MED classes, since the smallest class included only nine individuals. For the adult cohort (BIG, $N=126$ ) we observed a similar spatial pattern within a radius of $9 \mathrm{~m}$ from the focal individual $(C v M=6.99, P=0.002$, Figure 3B). A. pyrifolium was not analyzed here because of reduced recruitment.

The spatial association between $A$. pyrifolium and C. pyramidalis (bivariate analysis) was positive within a radius of $8 \mathrm{~m}(C v M=3.02, P=0.002)$ and for the higher distance classes there was a random spatial pattern (Figure 4). Additionally, we found a significant correlation $\left(r_{S}=0.464, P<0.05\right)$ between the spatial distribution of $A$. pyrifolium and C. pyramidalis.
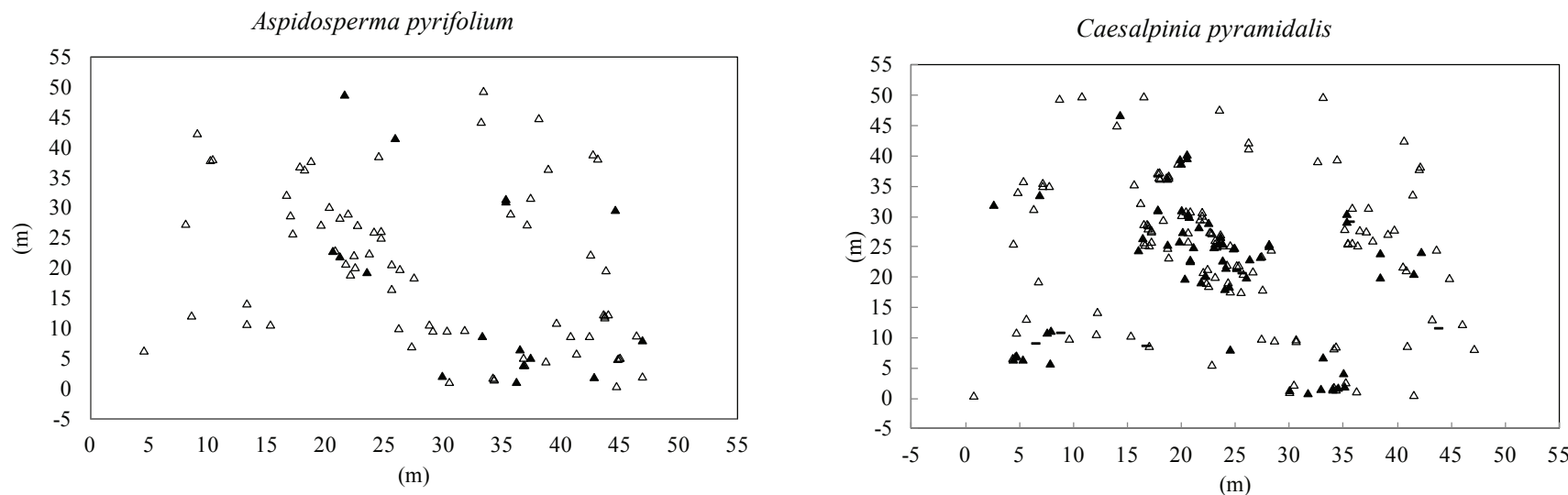

Figure 1. Distribution of the sampled adults $(\Delta)$, juveniles $(\boldsymbol{\Delta})$ and seedlings (-) of $A$. pyrifolium (A) and C. pyramidalis (B) in the sampled area of $2,500 \mathrm{~m}^{2}$. 

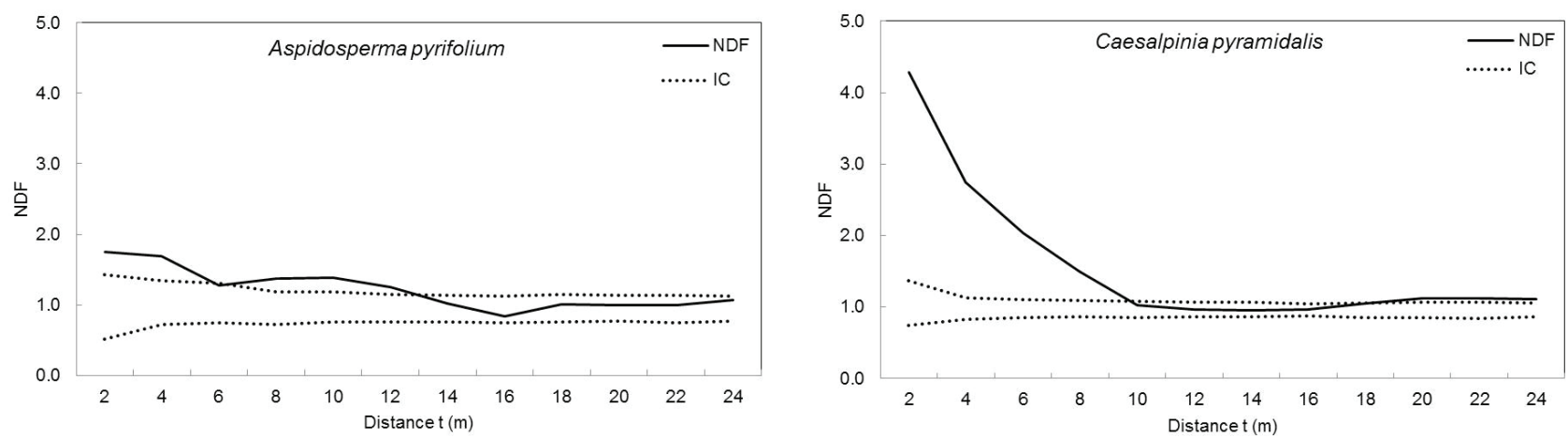

Figure 2. Spatial pattern obtained by univariate analysis of the neighborhood density function (NDF) of all plants of $A$. pyrifolium (A) and C. pyramidalis (B). Dotted lines correspond to the $99 \%$ range for the null hypothesis of completely random spatial distribution.
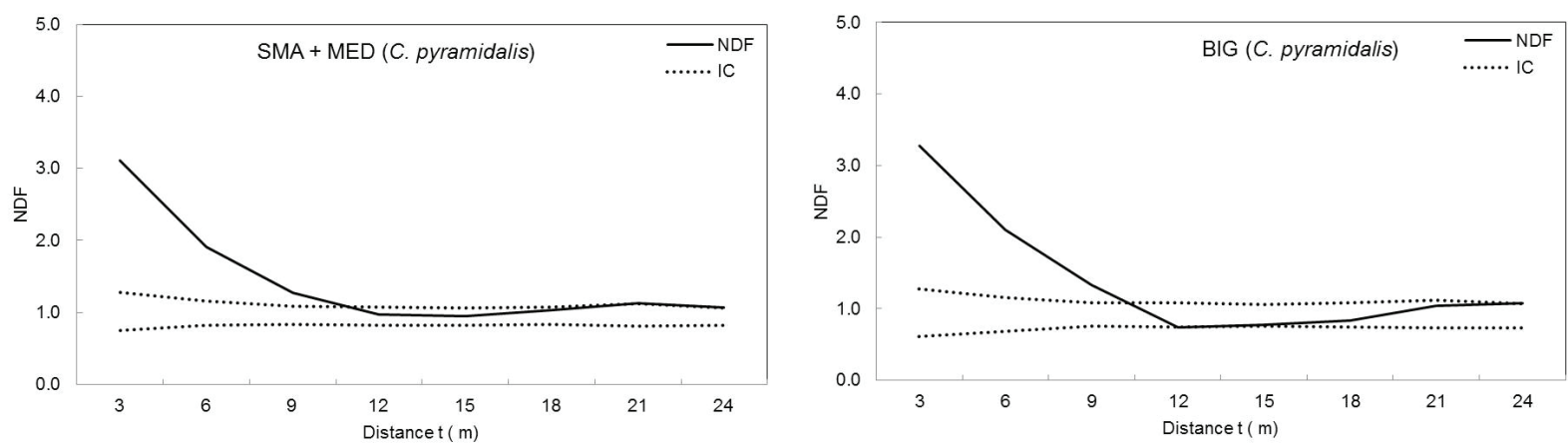

Figure 3. Spatial pattern obtained by univariate analysis of the neighborhood density function (NDF) for seedlings and juveniles (A) and for adults (B) of C. pyramidalis. Dotted lines correspond to the $99 \%$ range for the null hypothesis of completely random spatial distribution.

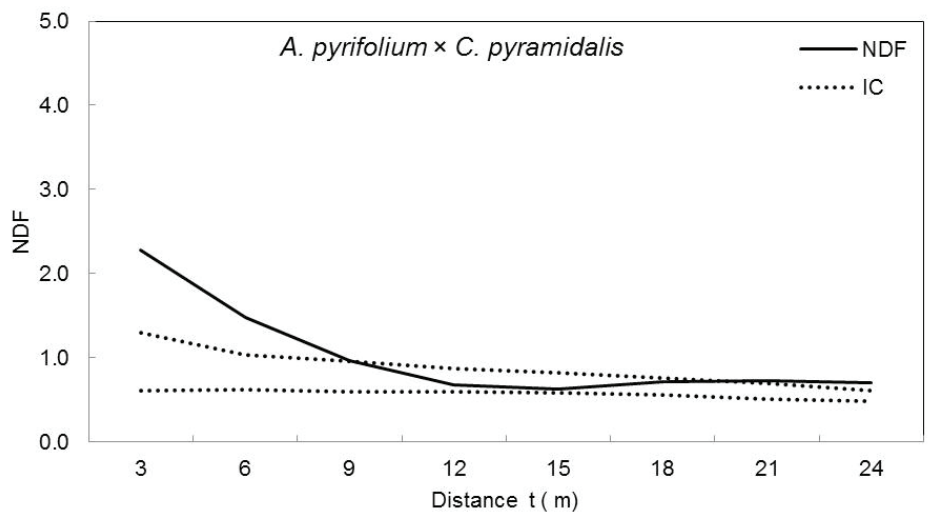

Figure 4. Bivariate analysis between C. pyramidalis and A. pyrifolium. Dotted lines correspond to the $99 \%$ range of for the null hypothesis of completely random spatial distribution. 


\section{Discussion}

The spatial patterning found is likely a reflection of the reproductive strategies of each species and the historical use of the site (Vieira et al., 2010). Due to autochorous dispersal, and based on theoretical predictions (Vekemans \& Hardy, 2004), we expected a more aggregate spatial pattern for $C$. pyramidalis than A. pyrifolium, which is anemochorous. However, the results showed that both C. pyramidalis and A. pyrifolium adults presented high neighbor density at short distances of up to $912 \mathrm{~m}$; however, the neighborhood density function was higher for the autochorous $C$. pyramidalis species (Figure 2).

As for the spatial patterning of cohorts, there was no difference between seedlings/juveniles (SMA + MED) and adults of the $C$. pyramidalis (BIG). This result differs from what is expected, as the literature reports that most tree species have aggregated spatial distribution during early life-stages and a random pattern for older life-stages (Hamrick et al., 1993, Epperson \& AlvarezBuylla, 1997). Furthermore, our result contradicts the Janzen-Connell hypothesis (Figure 3). It is likely that the similar aggregation values of the $C$. pyramidalis cohorts are associated with anthropogenic factors or abiotic conditions (periods of water-deficiency). The demographic structure reflects the history of the forest as well as past disturbances, including fire, herbivory and logging (Barot et al., 1999; Condit et al., 2000). More specifically, grazing by domesticated animals is associated with reduced recruitment and plant growth (Oba, 1998), as well as a reduced capacity for plant regeneration (Perevolotsky \& Haimov, 1992). In the studied site, there is intense grazing by domesticated animals that is associated with reduced recruitment or regeneration. Despite the fact that this areas has been designated as conservation unit for more than 30 years, the reduced species richness in the ESEC compared with other areas of Caatinga reflects the effect of past anthropogenic activities in the site, such as logging for timber and charcoal (Santana \& Souto, 2006).

In addition to the short distance aggregation pattern, there is considerable coexistence between the two species, as observed in the bivariate analysis of the neighbor density and the positive correlation of the Spearman coefficient. The magnitude of interspecific competition is still unknown but there is generally weak competition among some neotropical tree species (Paine et al., 2008). According to Byrne et al. (2007) the intensity with which individuals are aggregated affects the reproductive system and also how plants use available resources (Getzin et al., 2008). Thus, the aggregation of species could be explained by positive interspecific interactions such as facilitation. This process is common in semiarid regions with high stress conditions (Smit et al., 2009). It can also be explained simply by heterogeneity in the distribution of nutrients in the soil in the sample area which creates areas of greater fertility and therefore contributes to the association between A. pyrifolium and C. pyramidalis. However, future studies must move beyond spatial genetic structure and reproductive biology of these species to better understand such interactions.

\section{Acknowledgments}

The authors thank Coordenação de Aperfeiçoamento de Pessoal de Nivel Superior (CAPES) for providing a Doctoral Fellowship to C.G. Fajardo. We acknowledge Dr. Alexandre Vasconcellos and Dr. Carlos Fonseca for the field assistance, and Dr. Evelyn Nimmo for editing the English language of the manuscript. Also, we also thank the managers of Estação Ecológica do Seridó (ESEC) for their hospitality during fieldwork.

\section{References}

ANDRADE, L. A.; PEREIRA, I. M.; LEITE, U. T.; BARBOSA, M. R. Analyses of the stract of two Caatinga physionomy in São João do Cariri, Paraiba State. Cerne, Lavras, v. 11, n. 3, p. 253-262, 2005.

BAROT, S.; GIGNOUX, J.; MENAUT, J-C. Demography of a savanna palm tree: predictions from comprehensive spatial pattern analyses. Ecology, v. 80, p. 1987-2005, 1999.

BYRNE, M.; ELLIOTT, C. P.; YATES, C.; COATES, D. J. Extensive pollen dispersal in a bird-pollinated shrub, Calothamnus quadrifidus, in a fragmented landscape. Molecular Ecology, Oxford, v. 16, p. 1303-1314, 2007.

CONDIT, R.; ASHTON, P. S.; BAKER, P.; BUNYAVEJCHEWIN, S.; GUNATILLEKE, S.; GUNATILLEKE, N.; HUBBELL, S. P.; FOSTER, R. B.; ITOH, A.; LAFRANKIE, J. V.; LEE, H. S.; LOSOS, E.; MANOKARAN, N.; SUKUMAR, R.; YAMAKURA, T. Spatial patterns in the distribution of tropical tree species. Science, v. 288, p. 1414-1418, 2000.

CONNELL, J. H. On the role of natural enemies in preventing competitive exclusion in some marine animals and in rain forest trees. In: Den BOER, P. J.; GRADWELL, G. (Ed.). Dynamics of populations. Wageningen: Pudoc, 1971. p. 298-312.

COSTA, R. C.; ARAÚJO, F. S.; LIMA-VERDE, L. W. Flora and life-form spectrum in an area of deciduous thorn woodland (caatinga) in northeastern, Brazil. Journal of Arid Environments, London, v. 68 , p. 237-247, 2007. 
EPPERSON, B. K.; ALVAREZ BUYLLA, E. R. Limited seed dispersal and genetic structure in life stages of Cecropia obtusifolia. Evolution, v. 51, p. 275-282, 1977.

GETZIN, S.; WIEGAND, T.; WIEGAND, K.; HE, F. Heterogeneity influences spatial patterns and demographics in forest stands. Journal of Ecology, Oxford, v. 96, p. 807-820, 2008.

GIULIETTI, A. M.; DU BOCAGE NETA, A. L.; CASTRO, A. A. J. F.; GAMARRA-ROJAS, C. F. L.; SAMPAIO, E. V. S. B.; VIRGÍNIO, J. F.; QUEIROZ, L. P.; FIGUEIREDO, M. A.; RODAL, M. J. N.; BARBOSA, M. R. V.; HARLEY, R. M. Diagnóstico da vegetação nativa do bioma Caatinga. In: SILVA, J. M. C.; TABARELLI, M.; FONSECA, M. T.; LINS, L. V. (Org.). Biodiversidade da Caatinga: áreas e ações prioritárias para a conservação. Brasília, DF: Ministério do Meio Ambiente: Universidade Federal de Pernambuco, 2004. p. $48-90$.

GOREAUD, F.; PELISSIER, R. On explicit formulas of edge effect correction for Ripley's K-function. Journal of Vegetation Science, Knivsta, v. 10, p. 433-438, 1999.

HAASE, P. Spatial pattern analysis in ecology based on Ripley's K-function: introduction and methods of edge correction. Journal of Vegetation Science, Knivsta, v. 6, p. 575-582, 1995.

HAMRICK, J. L.; MURAWSKI, D. A.; NASON, J. D. The influence of seed dispersal mechanisms on the genetic-tructure of tropical tree populations. Vegetatio, The Hague, v. 108, p. 281-297, 1993.

JANZEN, D. H. Herbivores and the number of tree species in tropical forests. American Naturalist, Chicago, v. 104, p. 501-528, 1970.

LEAL, I. R.; SILVA, J. M. C.; TABARELLI, M.; LACHER JR, T. Changing the course of biodiversity conservation in the Caatinga of northeastern Brazil. Conservation Biology, Boston, v. 19, n. 3, p. 701-706, 2005.

LEITE, A. V.; MACHADO, I. C. Reproductive biology of catingueira (Caesalpinia pyramidalis Tul., Leguminosae-Caesalpinioideae), an endemic species of Caatinga. Brazilian Journal of Botany, São Paulo, v. 32, p. 79-88, 2009.

NG, K. K. S.; LEE, S. L.; KOH, C. L. Spatial structure and genetic diversity two tropical tree species with contrasting breeding systems and different ploidy levels. Molecular Ecology, Oxford, v. 13, p. 657-669, 2004.

OBA, G. Effects of excluding goat herbivory on Acacia tortilis woodland around pastoralist settlements in northwest Kenya. Acta Oecologica, Paris, v. 19, p. 395-404, 1998.

PAINE, C. E. T.; HARMS, K. E.; SCHNITZER, S. A.; CARSON, W. P. Weak competition among tropical tree seedlings: implications for species coexistence. Biotropica, Washington, US, v. 40, n. 4, p. 432-440, 2008.

PEREVOLOTSKY, A.; HAIMOV, Y. The effect of thinning and goat browsing on the structure and development of mediterranean woodland in Israel. Forest Ecology and Management, Amsterdam, v. 49, p. 61-74, 1992.
PERRY, G. L. W.; MILLER, B. P.; ENRIGHT, N. J. A comparison of methods for the statistical analysis of spatial point patterns in plant ecology. Plant Ecology, Dordrecht, v. 187, p. 59-82, 2006.

PERRY, G. L. W. SpPack: spatial point pattern analysis in Excel using Visual Basic for Applications (VBA). Environmental Modelling \& Software, Oxford, v. 19, p. 559-569, 2004.

SANTANA, J. A. S.; SANTANA JÚNIOR, J. A. S.; SOUTO, J. S.; MACÊDO, A. B. Water balance and thornthwaite climatic classification of the Seridó Ecological Station, Serra Negra do Norte-RN. Brasil Florestal, Brasília, DF, v. 23, n. 80, p. 9-16, 2006.

SANTANA, J. A. S.; SOUTO. J. S. Diversidade e estrutura fitossociológica da Caatinga na Estação Ecológica do Seridó-RN. Revista de Biologia e Ciências da Terra, v. 6, n. 2, p. 232-242, 2006.

SANTOS, J. C.; LEAL, I. R.; ALMEIDA-CORTEZ, J. S.; FERNANDES, G. W.; TABARELLI, M. Caatinga: the scientific negligence experienced by a dry tropical forest. Tropical Conservation Science, v. 4, p. 276-286, 2011a.

SANTOS, R. M.; BARBOSA, A. C. M. C.; ALMEIDA, H. S.; VIEIRA, F. A.; SANTOS, P. F.; CARVALHO, D. A.; OLIVEIRAFILHO, A. T. Structure and floristics of a remnant of arboreous caatinga in Juvenília, northern Minas Gerais, Brazil. Cerne, Lavras, v. 17 , p. $247-258,2011$ b.

SANTOS, R. M.; OLIVEIRA-FILHO, A. T.; EISENLOHR, P. V.; QUEIROZ, L. P.; CARDOSO, D. B. O. S.; RODAL, M. J. N. Identity and relationships of the Arboreal Caatinga among other floristic units of seasonally dry tropical forests (SDTFs) of Northeastern and Central Brazil. Ecology and Evolution, v. 2, p. 409-428, 2012.

SMIT, C.; RIETKERK, M.; WASSEN, M. J. Inclusion of biotic stress (consumer pressure) alters predictions from the stress gradient hypothesis. Journal of Ecology, Oxford, v. 97, n. 6, p. 1215-1219, 2009.

STATSOFT. Statistica (data analysis software system), version 7. Tulsa, 2004.

THORNTHWAITE, C. W.; MATHER, J. R. The water balance. Centerton: Laboratory of Climatology, 1955. 104 p. (Publications in Climatology, v. 8, n. 1).

VEKEMANS, X.; HARDY, O. J. New insights from fine-scale spatial genetic structure analysis in plant populations. Molecular Ecology, Oxford, v. 13, p. 921-935, 2004..

VIEIRA, F. A.; CARVALHO, D.; HIGUCHI, P. MACHADO, E. L. M.; SANTOS, R. M. Spatial pattern and fine-scale genetic structure indicating recent colonization of the palm Euterpe edulis in a Brazilian Atlantic forest fragment. Biochemical Genetics, New York, v. 48, p. 96-103, 2010.

VIEIRA, F. A.; FAJARDO, C. G.; SOUZA, A. M.; REIS, C. A. F.; CARVALHO, D. Fine-scale genetic dynamics of a dominant neotropical tree in the threatened Brazilian Atlantic Rainforest. Tree Genetics \& Genomes, v. 8, p. 1191-1201, 2012. 